\title{
VOLTAGE LEVEL IMPROVEMENT OF KHARTOUM LOCAL MARKET 110kV SUBSTATION
}

\author{
[Mohamed.M.K.Boshara]
}

\begin{abstract}
The main goal of this study is to improve the voltage at Khartoum Local Market $110 \mathrm{kV}$ substation as one of substations of Khartoum Ring Network. Static VAR Compensator has been used to contribute to the improvement of the decline in the voltage at the substation resulting from the different operating conditions. ETAP software has been used in the analysis to determine the effectiveness of this technique in the improvement process.
\end{abstract}

The results obtained were satisfactory and as expected.

Keywords - Voltage level improvement, Static VAR compensator, Reduction of system losses, ETAP software.

\section{Introduction}

Demands on electrical transmission system are increasing every day because of the increasing number of customers. Absence of long term planning and the necessity to provide open access to customers, all together have resulted in diminished security and poor quality of supply [1]. However, the electric power system is an exceedingly nonlinear system that operates in changing environmental conditions. Loads, generator outputs, topology, and key operating parameters change continually [2]. All this lead to decrease of voltage in the network. Static VAR Compensator is one of the techniques used to provide solution to this problem.

Static VAR Compensator can be linked to the terminal substation in the power distribution system to reduce the reactive power, enhance the power factor, decrease the distribution system losses and reduce the damages brought on by frequent switching-in of capacitor banks [3].

\section{Khartoum Network Substations}

Khartoum Ring Network contains Seventeen substations. The total length of the Ring is $232 \mathrm{~km}$, double circuited. Six of these substations are among the nine substations in SUDAN Grid which have or suggested to connect Static VAR

Mohamed .M. Boshara (Auther)

Faculty of Engineering / University of Medical Sciences and Technology (UMST).

Sudan.
Compensator, because Ring thus have problems of voltage level decrease. One of them is local Market $110 \mathrm{kV}$ substation. In this study it is suggested to connect static VAR compensator at this substation and study the feasibility of improvement in the voltage level.

Local Market Substation contains two transformers with a capacity of 100MVA each. Each is supplied by two-lines are line from Kilo-X $110 \mathrm{kV}$ substation and the other line from Shagara $110 \mathrm{kV}$ substation [4]. The total load in the substation is $110.4 \mathrm{MW}$. The substation feeds loads in the industrial area south of Khartoum, as well as supplying residential and commercial loads. Figure (1) refers to the single line diagram of the substation.

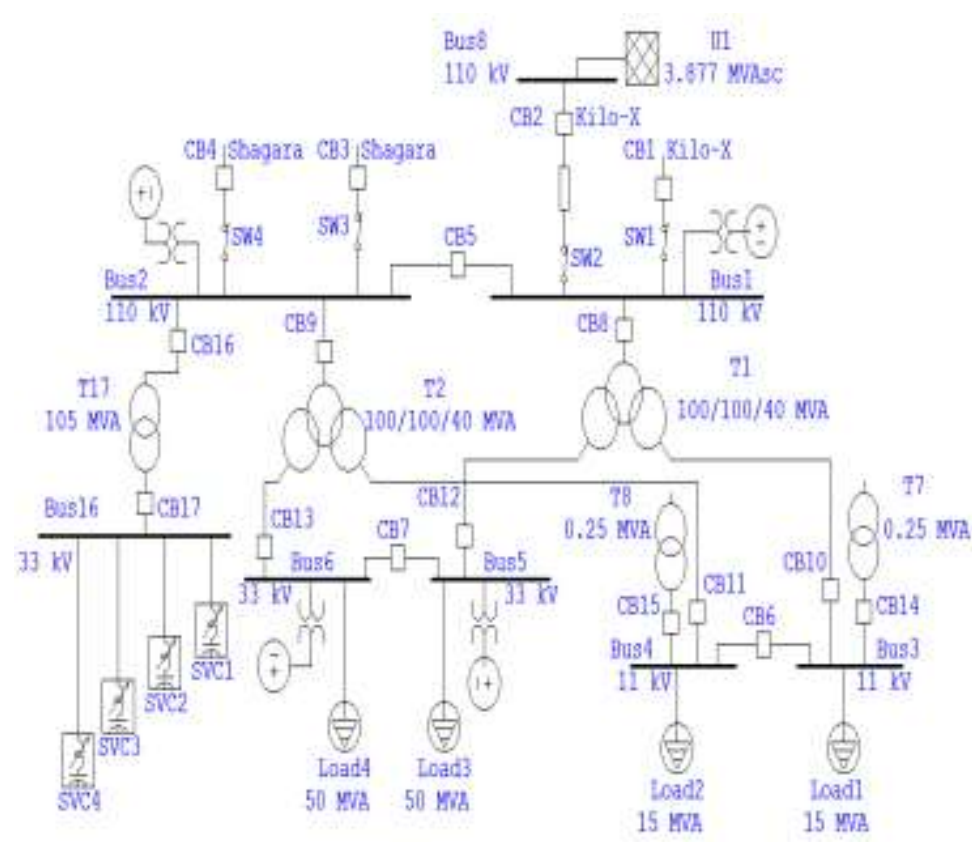

Figure (1): Single Line Diagram of Local Market Substation with SVC.

\section{A. Static VAR Compensators}

Static VAR Compensators (SVCs) are shunt linked static generators and/or absorbers of reactive power whose outputs are varied in order to control specific parameters of the electrical power system [5]. They are electrical devices for giving quick-acting reactive power compensation on high voltage transmission systems and thus can contribute to the improvement of the voltage profiles in the transient state and subsequently, they can improve the quality and of the electric supply [6]. 


\section{B. Method}

During the peak load, the load increases and the voltage decreases, so in this case the capacitor starts to work, because this decreasing affects the efficiency of the substation transformers.

When the load decreases, the voltage increases and the reactor starts to work to solve this problem, because the increase in the voltage affects the cables and insulations. Thus this above process is accomplished by Static VAR Compensator (SVC), which comprises both capacitors and reactors.

\section{Implementation of ETAP Software}

ETAP software is used in this study, because of its efficiency, accuracy and simplicity.

The basic data of the substations is as follows:

- Load 110.4MW

- Power factor 0.85

- Short circuit current for $110 \mathrm{kV}$ bus:

$$
I_{1-p}=22.67\left\llcorner-83.3, I_{3-P}=20.35\llcorner-83.4\right.
$$

From the data given, it is necessary to calculate some of the required parameters of the lines coming into the substation from other stations so as to know the amount of power drawn from them.

$$
\mathrm{X} / \mathrm{R}=\tan \Phi
$$

- Values of $(X / R)$ for 3-phase and 1-phase are:

$$
\begin{aligned}
& X / R_{(3-p h)}=\tan (-83.4)=-8.643^{\circ} . \\
& X / R_{(1-p h)}=\tan (-83.3)=-8.513^{\circ} .
\end{aligned}
$$

- Value of MVA for both, 1-phase and 3-phase are:

$\operatorname{MVA}(3-\mathrm{ph})=\sqrt{ } 3 * 110 * 20.35=3.877 \mathrm{MVA}$

MVA $(1-\mathrm{ph})=\operatorname{MVA}(3-\mathrm{ph}) / 3=1.292 \mathrm{MVA}$

For load busses:

$$
\begin{aligned}
& \mathrm{P}=\mathrm{S}+\mathrm{jQ} \text {. } \\
& \mathrm{P}=\mathrm{S} \cos \Phi \rightarrow \mathrm{S}=\mathrm{P} / \cos \Phi=110.4 / 0.85 \\
& \mathrm{~S}=129.5 \approx 130 \mathrm{MVA}
\end{aligned}
$$

- 130 MVA from Equation (3) refers to apparent power (S) in MVA. It has been computed to be 130MVA, using Pf = 0.85.This apparent power has been divided among feeders with voltage level $33 \mathrm{kV}$ and $11 \mathrm{kV}$ as follows:

\begin{tabular}{|c|c|c|}
\hline Feeder & $\begin{array}{c}\text { Voltage Load in } \\
\mathrm{kV}\end{array}$ & $\begin{array}{c}\text { Apparent Power in } \\
\text { MVA }\end{array}$ \\
\hline Feeder-1 & 33 & 50 \\
\hline Feeder-2 & 33 & 50 \\
\hline Feeder-3 & 11 & 15 \\
\hline Feeder-4 & 11 & 15 \\
\hline
\end{tabular}

\section{A. Static VAR Compensator Models}

There are three types of control models in ETAP software. These are variable impendence type, current source type and voltage source type. In addition, ETAP program has two important values of parameters for static VAR compensator, capacitive load $\left(\mathbf{Q}_{\mathbf{C}}\right)$ and inductive $\operatorname{load}\left(\mathbf{Q}_{\mathbf{L}}\right)$. In this study only one of these types is used for controlling the static VAR compensator. Table (1) refers to the maximum and minimum value of capacitive and inductive loads. The maximum voltage taken is $10 \%$ above the rated voltage.

Table (1): Values of capacitive and inductive loads.

\begin{tabular}{|c|c|c|c|}
\hline & $\begin{array}{c}\text { Maximum } \\
\text { Value }\end{array}$ & $\begin{array}{c}\text { Minimum } \\
\text { Value }\end{array}$ & Unit \\
\hline $\mathbf{Q}_{\mathbf{L}}$ & 30 & 0 & $\mathrm{MVAr}$ \\
\hline $\mathbf{Q}_{\mathbf{C}}$ & 70 & 62.08 & $\mathrm{MVAr}$ \\
\hline
\end{tabular}

\section{RESEULTS OF LOAD FLOW}

\section{A. Result of Load Flow without SVC}

Table (2): Critical Report without SVC.

\begin{tabular}{|l|c|c|c|c|}
\hline $\begin{array}{c}\text { Bus No } \\
(3-\varnothing)\end{array}$ & Condition & $\begin{array}{c}\text { Rating / } \\
\text { Limit }\end{array}$ & Operation & $\begin{array}{c}\text { \% } \\
\text { Operation }\end{array}$ \\
\hline Bus-3 & Under Voltage & $11.00 \mathrm{kV}$ & 10.156 & 92.3 \\
\hline Bus-4 & Under Voltage & $11.00 \mathrm{kV}$ & 10.153 & 92.3 \\
\hline Bus-5 & Under Voltage & $33.00 \mathrm{kV}$ & 30.840 & 93.5 \\
\hline Bus-6 & Under Voltage & $33.00 \mathrm{kV}$ & 30.830 & 93.4 \\
\hline
\end{tabular}

Table (3): Total Generation and Demand (Load).

\begin{tabular}{|c|c|c|c|c|}
\hline Swing Buses & 108.791 & 81.195 & 135.75 & $\begin{array}{c}80.14 \\
\text { lagg }\end{array}$ \\
\hline $\begin{array}{c}\text { Non-Swing } \\
\text { Buses }\end{array}$ & 0.000 & 0.000 & 0.000 & Mvar \\
\hline $\begin{array}{c}\text { Total Demand } \\
\text { Total } \\
\text { Motor Load }\end{array}$ & 108.791 & 81.195 & 135.75 & $\begin{array}{c}85.00 \\
\text { lagg }\end{array}$ \\
\hline $\begin{array}{c}\text { Total } \\
\text { Static Load }\end{array}$ & 19.189 & 11.892 & 22.575 & $\begin{array}{c}80.14 \\
\text { lag }\end{array}$ \\
\hline $\begin{array}{c}\text { Total } \\
\text { Constant Load }\end{array}$ & 0.000 & 0.000 & 0.000 & 0.000 \\
\hline $\begin{array}{c}\text { Total Generic } \\
\text { Load }\end{array}$ & 0.000 & 0.000 & 0.000 & 0.000 \\
\hline Apparent Losses & 1.202 & 14.518 & & \\
\hline System Mismatch & 0.000 & 0.000 & 0.000 & \\
\hline
\end{tabular}

Going through tables (2), (3) it is noted that there is a clear voltage drop before using SVC. The voltage registered at $33 \mathrm{kV}$ bus bar and $11 \mathrm{kV}$ bus bar is $30.84 \mathrm{kV}$ and $10.156 \mathrm{kV}$ respectively .So there is a real need to use SVC at this substation to correct the voltage level to its nominal voltage values. 
Proc. of the Fifth Intl. Conf. Advances in Computing, Communication and Information Technology- CCIT 2017

Copyright (C) Institute of Research Engineers and Doctors, USA .All rights reserved.

ISBN: 978-1-63248-131-3 doi: 10.15224/ 978-1-63248-131-3-22

\section{B. Result of Load Flow with SVC}

Table (4): Critical Report with SVC at the maximum voltage.

\begin{tabular}{|c|c|c|c|c|}
\hline $\begin{array}{c}\text { Bus } \\
\text { No } \\
\text { (3-Ø) }\end{array}$ & Condition & $\begin{array}{l}\text { Rating/ } \\
\text { Limit }\end{array}$ & Operation & \% Operation \\
\hline Bus-1 & Over Voltage & $110.00 \mathrm{kV}$ & 119.916 & 109.0 \\
\hline Bus-2 & Over Voltage & $110.00 \mathrm{kV}$ & 119.916 & 109.0 \\
\hline Bus-8 & Over Voltage & $110.00 \mathrm{kV}$ & 121.000 & 110.0 \\
\hline
\end{tabular}

Table (5): Marginal Report with SVC at the maximum voltage.

\begin{tabular}{|c|c|c|c|c|}
\hline $\begin{array}{c}\text { Bus } \\
\text { No } \\
(3-\varnothing)\end{array}$ & Condition & $\begin{array}{l}\text { Rating/ } \\
\text { Limit }\end{array}$ & Operation & \% Operation \\
\hline Bus-16 & Over Voltage & $33.00 \mathrm{kV}$ & 34.430 & 104.3 \\
\hline Bus-3 & Over Voltage & $11.00 \mathrm{kV}$ & 11.279 & 102.5 \\
\hline Bus-4 & Over Voltage & $11.00 \mathrm{kV}$ & 11.276 & 102.5 \\
\hline Bus-5 & Over Voltage & $33.00 \mathrm{kV}$ & 34.185 & 103.6 \\
\hline Bus-6 & Over Voltage & $33.00 \mathrm{kV}$ & 34.176 & 103.6 \\
\hline
\end{tabular}

Table (6): Total Generation and Demand (load) at the maximum voltage.

\begin{tabular}{|c|c|c|c|c|}
\hline & MW & Mvar & MVA & PF\% \\
\hline Swing Buses & 113.543 & 134.334 & 175.891 & 64.55 lagg \\
\hline $\begin{array}{c}\text { Non-Swing } \\
\text { Buses }\end{array}$ & 0.000 & 0.000 & 0.000 & \\
\hline Total Demand & 113.543 & 134.334 & 175.891 & 64.55 lagg \\
\hline $\begin{array}{c}\text { Total } \\
\text { Motor Load }\end{array}$ & 88.400 & 54.795 & 104.005 & 85.00 lagg \\
\hline $\begin{array}{c}\text { Total } \\
\text { Static Load }\end{array}$ & 23.599 & 63.961 & 68.176 & 34.61 lagg \\
\hline $\begin{array}{c}\text { Total } \\
\text { Constant Load }\end{array}$ & 0.000 & 0.000 & 0.000 & 0.000 \\
\hline $\begin{array}{c}\text { Total } \\
\text { Generic Load }\end{array}$ & 0.000 & 0.000 & 0.000 & 0.000 \\
\hline Apparent Losses & 1.544 & 15.577 & & \\
\hline System Mismatch & 0.000 & 0.010 & & \\
\hline
\end{tabular}

Table (7): Critical Report with SVC at the minimum voltage.

\begin{tabular}{|c|c|c|c|c|}
\hline $\begin{array}{c}\text { Bus } \\
\text { No } \\
(3-\varnothing)\end{array}$ & Condition & $\begin{array}{c}\text { Rating/ } \\
\text { Limit }\end{array}$ & $\begin{array}{c}\text { Operatio } \\
\text { n }\end{array}$ & \% Operation \\
\hline Bus-1 & Under Voltage & $110.000 \mathrm{kV}$ & 90.053 & 81.9 \\
\hline Bus-2 & Under Voltage & $110.000 \mathrm{kV}$ & 90.053 & 81.9 \\
\hline Bus-3 & Under Voltage & $11.000 \mathrm{kV}$ & 8.093 & 73.6 \\
\hline Bus-4 & Under Voltage & $11.000 \mathrm{kV}$ & 8.093 & 73.5 \\
\hline Bus-5 & Under Voltage & $33.000 \mathrm{kV}$ & 24.715 & 74.9 \\
\hline Bus-6 & Under Voltage & $33.000 \mathrm{kV}$ & 24.703 & 74.9 \\
\hline Bus-8 & Under Voltage & $110.000 \mathrm{kV}$ & 90.000 & 81.8 \\
\hline T17 & Over Load & 105.000 & 132.399 & 126.1 \\
\hline
\end{tabular}

Table (8): Marginal Report with SVC at the minimum voltage.

\begin{tabular}{|c|c|c|c|c|}
\hline $\begin{array}{c}\text { Bus No } \\
\text { (3-Ø) }\end{array}$ & Condition & $\begin{array}{c}\text { Rating / } \\
\text { Limit }\end{array}$ & Operation & \% Operation \\
\hline Bus-16 & $\begin{array}{c}\text { Under } \\
\text { Voltage }\end{array}$ & $33.000 \mathrm{kV}$ & 31.530 & 95.5 \\
\hline
\end{tabular}

Table (9): Total Generation and Demand (load) at the minimum voltage.

\begin{tabular}{|c|c|c|c|c|}
\hline Swing Buses & 105.048 & -31.526 & 109.677 & $\begin{array}{c}95.78 \\
\text { lead }\end{array}$ \\
\hline $\begin{array}{c}\text { Non-Swing } \\
\text { Buses }\end{array}$ & 0.000 & 0.000 & 0.000 & \\
\hline Total Demand & 105.048 & -31.526 & 109.677 & 95.78 lead \\
\hline $\begin{array}{c}\text { Total } \\
\text { Motor Load }\end{array}$ & 88.400 & 54.776 & 103.995 & 85.00 lead \\
\hline $\begin{array}{c}\text { Total } \\
\text { Static Load }\end{array}$ & 12.290 & -124.77 & 125.376 & 9.80 lead \\
\hline $\begin{array}{c}\text { Total } \\
\text { Constant Load }\end{array}$ & 0.000 & 0.000 & 0.000 & \\
\hline $\begin{array}{c}\text { Total Generic } \\
\text { Load }\end{array}$ & 0.000 & 0.000 & 0.000 & \\
\hline Apparent Losses & 4.358 & 38.471 & & \\
\hline System Mismatch & 0.000 & 0.010 & & \\
\hline \multicolumn{2}{|c|}{} & & & \\
\hline
\end{tabular}

Results in tables No (4), (5) and (6), show that there is an improvement in the substation voltage profile when $(-10 \%)$ inductive MVAR has been absorbed to the system. The voltage has improved to $110 \mathrm{kV}$ at $110 \mathrm{kV}$ bus bar, $34.18 \mathrm{kV}$ at $33 \mathrm{kV}$ and $11.27 \mathrm{kV}$ at $11 \mathrm{kV}$ bus bar.

The results in tables No (7), (8) and (9), show that there is an improvement in the substation voltage profile to its nominal values when $(+10 \%)$ capacitive MVAR has been injected to the system. The voltage has been improved to $33 \mathrm{kV}$ instead of $24.72 \mathrm{kV}$ and $11 \mathrm{kV}$ instead of $8.093 \mathrm{kV}$.

\section{CONCLUSION}

In this study, the system under consideration has been simulated using ETAP software under the following assumptions:

- Local Market substation $110 \mathrm{kV}$ bus bar voltage will increase to a maximum value of $121 \mathrm{kV}$ (i.e. $+10 \%$ ).

- Local Market substation $110 \mathrm{kV}$ bus bar voltage will drop to a minimum value of $90 \mathrm{kv}$ (i.e. $-10 \%$ ).

After connection of static VAR compensator: Under maximum voltage assumption (i.e. $121 \mathrm{kV}$ ) the bus bar has been improved to the nominal voltage value of $(110 \mathrm{kV})$ due to absorption of inductive load (-MVAr) by the action of the static VAR compensator connection. Under minimum voltage assumption (i.e. $90 \mathrm{kV}$ ) the bus bar voltage has been improved to the nominal operating value of $110 \mathrm{kv}$ due to injection of capacitive load (+MVAr). 


\section{Further Work}

It is recommended to use SVC as reactive power compensator in this case study, because it is economically and technically feasible. Moreover, SVC is a static machine which means free maintenance and no fuel consumption, simplicity and flexibility in operation. SVC can be used as one package in both high/low voltage cases of the power system.

Studies are recommended to be conducted in other substations in the SUDAN Grid to improve the voltage profile of the system and accordingly reduce the energy losses.

\section{References}

[1] Md M. Biswas, Kamol K. Das, "Voltage Level Improving by Using Static VAR Compensator (SVC) ", Global Journal of researches in engineering, Volume 11, Issue 5, Version 1.0 July 2011.

[2] Astha Dua, Surya Prakash, "Voltage Level Improvement of Power System by Using Static Synchronous Series Compensator with POD", International Journal of Engineering Research \& Technology (IJERT), Volume 2, Issue 5, May 2013.

[3] http://www.nari-relays.com/.

[4] Sudanese Electricity Transmission Company. LTD.

[5] Kundur. Prabha, "Power System Stability and Control", Third Edition, McGraw-Hill-Ch.11pp.627-641, Jun 2012.

[6] Habibur Rahman, Md. Fayzur Rahman, Harun-Or-Rashid, "Voltage Level Improvement of Power System by Using SVC with POD Controller", International Journal of Advanced Technology \& Engineering Research (IJATER), Volume 2, Issue 4, July 2012.

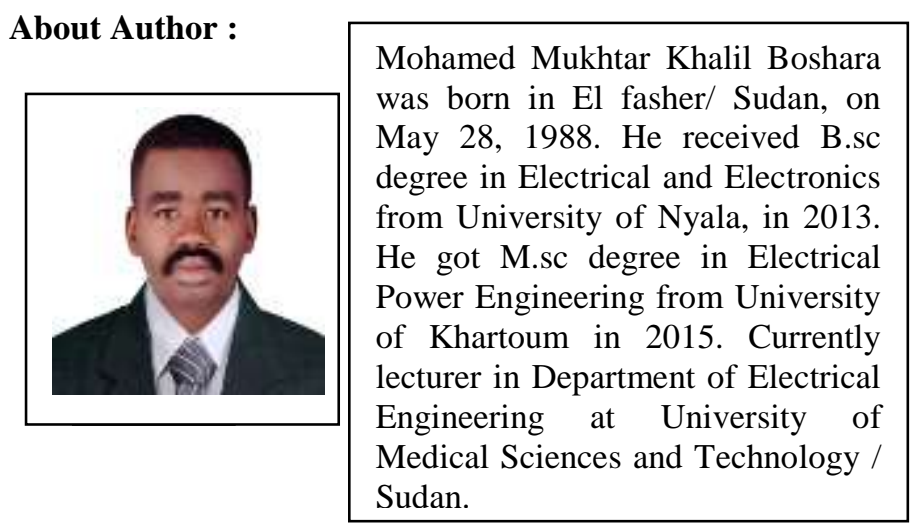

